\title{
Hyaline cast formation in patients treated with cephaloridine
}

\author{
W. D. LINSELL, A. PINES, AND J. W. HAYDEN \\ From Ware Park Hospital, Hertford, and the Herts and Essex General Hospital, \\ Bishops Stortford, Herts.
}

SYNOPSIS The administration of $6 \mathrm{~g}$. cephaloridine daily produced large numbers of hyaline casts during treatment, occasionally accompanied by red and white cells and albumin. These cleared when treatment ended and are of uncertain and doubtful significance.

Routine examination of the urine of patients suffering from acute exacerbations of chronic bronchitis and receiving treatment with cephaloridine showed in some cases an unusually large number of urinary casts in the centrifuged deposit. In a comparative trial of cephaloridine with other antibiotics during the winter of 1965/66 (Pines, Raafat, Plucinski, Greenfield, and Linsell, 1967), it was decided to carry out a quantitative assessment of urinary cast production in a group of patients treated with cephaloridine and a 'control' group treated with other antibiotics. This was considered to be of importance in view of the fact that the cephaloridine-treated group was to receive $6 \mathrm{~g}$. per day of the antibiotic. This large dose régime has been shown to be effective with other antibiotics, such as ampicillin (Pines, 1964), and it was decided to test its clinical effectiveness, thus making it all the more necessary to assess any possible untoward renal tract complications.

\section{METHOD}

A group of 29 patients receiving $6 \mathrm{~g}$. of cephaloridine daily for 14 days and 14 control patients receiving other antibiotics (11 ampicillin, two penicillin plus streptomycin, and one streptomycin), had morning urine samples

Received for publication 29 March 1967. collected for 14 days during treatment and for 14 days following treatment. A $15 \mathrm{ml}$. aliquot sample of urine was contrifuged in an M.S.E. minor centrifuge at 1,500 r.p.m. for five minutes, the deposit being resuspended in $1 \mathrm{ml}$. of urine to give a standard volume. Casts were counted using an improved Neubauer counting chamber, and a similar count was carried out on any red cells and white cells present in the deposit. Later in the trial it was decided to observe the effect of combining cephaloridine $(6 \mathrm{~g}$. per day) with probenecid ( $3 \mathrm{~g}$. per day) to see if probenecid prevented tubular cell damage which might have been caused by cephaloridine resulting in the outpouring of casts found during the early period of the trial.

\section{RESULTS}

Examination of the urine of the patients on the $6 \mathrm{~g}$. daily cephaloridine régime and on the cephaloridine plus probenecid régime showed that all produced an excess of urinary casts at some time during treatment. Production of casts was variable, in some cases being so heavy as to be uncountable in the ordinary urinary deposit and to exceed in quantity anything before seen by us in other conditions of renal pathology. The great majority of patients excreted hyaline casts and in a few cases these were accompanied by small numbers of granular casts.

Table I shows the figures obtained for the average

TABLE I

AVERAGE DAILY CAST COUNTS IN 29 PATIENTS DURING 14 DAYS OF CEPHALORIDINE TREATMENT AND FOR 14 DAYS AFTER TREATMENT AND THE HIGHEST COUNT OBTAINED

Cast Count

Day

\begin{tabular}{|c|c|c|c|c|c|c|c|c|c|c|c|c|c|c|}
\hline & $\boldsymbol{I}$ & 2 & 3 & 4 & 5 & 6 & 7 & 8 & 9 & 10 & 11 & 12 & 13 & 14 \\
\hline Average during 14 days of cephaloridine & 2 & 10 & 25 & 10 & 18 & 32 & 20 & 14 & 20 & 18 & 13 & 21 & 18 & 14 \\
\hline Average after cephaloridine & 10 & 4 & 3 & 2 & 5 & 5 & 3 & 1 & $\mathbf{0}$ & $\mathbf{0}$ & 1 & 1 & $\mathbf{0}$ & $\mathbf{0}$ \\
\hline Highest obtained during cephaloridine & 20 & 100 & 150 & $\begin{array}{r}80 \\
8\end{array}$ & 120 & 150 & 90 & 80 & 100 & 120 & 80 & 120 & 100 & 80 \\
\hline
\end{tabular}


TABLE II

AVERAGE DAILY CAST COUNT IN 14 CONTROL GROUP PATIENTS

\begin{tabular}{|c|c|c|c|c|c|c|c|c|c|c|c|c|c|c|}
\hline & \multicolumn{14}{|c|}{ Day } \\
\hline & 1 & 2 & 3 & 4 & 5 & 6 & 7 & 8 & 9 & 10 & 11 & 12 & 13 & 14 \\
\hline Average daily cast count during treatment & 5 & $\mathbf{0}$ & $\mathbf{0}$ & $\begin{array}{l}\text { Less } \\
\text { than } \\
1\end{array}$ & 0 & $\begin{array}{l}\text { Less } \\
\text { than } \\
1\end{array}$ & 1 & $\begin{array}{l}\text { Less } \\
\text { than } \\
1\end{array}$ & $\begin{array}{l}\text { Less } \\
\text { than } \\
1\end{array}$ & $\mathbf{0}$ & $\begin{array}{l}\text { Less } \\
\text { than } \\
1\end{array}$ & $\begin{array}{l}\text { Less } \\
\text { than } \\
1\end{array}$ & 0 & 0 \\
\hline
\end{tabular}

TABLE III

COUNTS OBTAINED IN NINE PATIENTS GIVEN CEPHALORIDINE PLUS PROBENECID

\begin{tabular}{|c|c|c|c|c|c|c|c|c|c|c|c|c|c|c|}
\hline & \multicolumn{14}{|c|}{ Day } \\
\hline & 1 & 2 & 3 & 4 & 5 & 6 & 7 & 8 & 9 & 10 & 11 & 12 & 13 & 14 \\
\hline Average daily cast counts during treatment & 4 & 7 & 3 & 5 & 12 & 20 & 7 & 22 & 10 & 17 & 12 & 10 & 11 & 29 \\
\hline Highest cast count & 4 & 25 & 10 & 25 & 60 & 60 & 15 & 80 & 30 & 70 & 60 & 30 & 40 & 80 \\
\hline
\end{tabular}

daily cast counts per c.mm. of $1 \mathrm{ml}$. resuspended deposit for 14 days during treatment and 14 days after treatment in 29 male patients of average age 61 years. In general it can be said that during cephaloridine treatment a consistently high cast count resulted which subsided on cessation of treatment.

Table II shows the results of investigating the 14 control patients; these again were men of an average age of 57 years with similar clinical features to those in the cephaloridine-treated group; 11 received ampicillin, $4 \mathrm{~g}$. per day orally with $3 \mathrm{~g}$. intramuscularly, and in addition for the first three days, two patients received penicillin 4 million units plus streptomycin $1 \mathrm{~g}$. per day, and one patient streptomycin $1 \mathrm{~g}$. per day. From the results it will be seen that only two of these showed hyaline casts in countable quantity and then at only low figures. Both these patients were severely ill with heart failure due to cor pulmonale.

As a result of these observations it was decided to observe the effect of combining cephaloridine $(6 \mathrm{~g}$. per day) with probenecid ( $3 \mathrm{~g}$. per day) to see if the latter drug prevented antibiotic being secreted into the tubules and possibly causing cellular damage. Table III shows the results obtained in nine such patients, again a similar clinical group, and of an average age of 63 years. All were men. Cast counts were slightly, but not significantly, lower than in the cephaloridine group.

\section{OTHER OBSERVATIONS}

RED AND WHITE BLOOD CELLS In the cephaloridine group (29 patients), six excreted 5 or more red cells per c.mm. as a daily average, the highest figure being 82. White cell counts exceeded 5 per c.mm. in five patients, the highest being 38. Compared with the control group red cell excretion appeared considerably higher in the cephaloridine-treated group but there was no appreciable difference with white cell excretion.

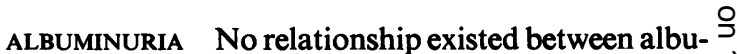
minuria and urinary cast excretion:only two patients $\vec{z}$ in the cephaloridine group had detectable albuminuria, one of these having a high cast count and the other a low one.

BLOOD UREA This was estimated twice in every case. $\vec{\bullet}$ The highest figure obtained was $80 \mathrm{mg}$. per $100 \mathrm{ml}$. in a patient with heart failure who had a comparatively low cast excretion rate. There appeared to be no relationship between blood urea levels and urinary cast and cell excretion.

FOLLOW-UP URINARY EXAMINATION Three of the heaviest cast excretors were followed up at intervals for nine months after ceasing treatment with cephal- $\exists$ oridine. No recurrence of cast excretion or evidence of renal damage has been found in these cases.

\section{DISCUSSION}

Our results show that the high dose of cephaloridine used causes high hyaline cast excretion, often in extremely large amounts, which does not occur in 0 patients receiving similar therapy with other antibiotics. Care was taken to distinguish hyaline casts from urinary 'cylindroids' and no difficulty was experienced; the hyaline casts seen were quite typical. $\%$ In the severely ill patients investigated, congestion of $\mathrm{N}$ the kidneys, some degree of oedema, and possible N్ toxic tubular or glomerular damage associated with $\sigma$ infection and pyrexia could account for a degree of proteinuria possibly with cast production. However, specimens examined on or before the first day of $\stackrel{\Phi}{\mathcal{D}}$ treatment yielded hyaline casts in only scanty numbers in two of the control patients and also in 100 of the patients treated with cephaloridine.

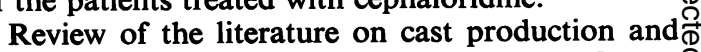
Addis counts in normal individuals gives figures 
varying between 0.002 million (Campbell, 1963) to 0.009 million in adults and 0.015 million in aged adults in 24 hours (Sodeman, 1961). In our series conversion from numbers per c.mm. to 24-hour output gives figures ranging between 0.2 million and 15 million, i.e., up to 1,000 times the normal ranges quoted above. This is probably much below the true figure because casts may have been incompletely centrifuged and also they may have disintegrated during centrifugation. For this reason we consider that the comparison between cephaloridine-treated patients and control patients is more valid. Further, these patients were all immobilized in bed and the possibility of postural or orthostatic proteinuria with cast production could only be assessed by comparing two groups of approximately similar age and clinical state.

The mechanism of cast production in these cases appears to be unassociated with any degree of proteinuria detectable by routine salicylsulphonic acid testing. The casts may not be of albumin but of other protein origin. Analysis of the casts is currently under investigation. The absence of detectable albuminuria and the disassociated occurrence of red and white cells in the urinary deposit indicates that the cast formation may not be due to glomerular damage of any great degree but suggests that it may be due to a diminished tubular reabsorption of protein.

This phenomenon does not to our knowledge occur with any of the newer antibiotics. Allen, Roberts, and
Kirby (1962) reported the occurrence of transient microscopic haematuria with oliguria and azotaemia but without casts in 22 cases of septicaemia treated with methicillin. Gratton (1964) reported a similar observation due, in his opinion, to methicillin administration. Feigin and Fiascone (1965) described haematuria and proteinuria during methicillin treatment of a child with lung abscess. Albuminuria of gross degree appeared after the 23rd day of treatment but disappeared on the seventh day after changing the treatment to erythromycin and chloramphenicol.

In our patients follow-up has shown no evidence of renal damage or recurrence of cast excretion.

Those engaged in the routine urine microscopy of patients receiving high doses of cephaloridine should be aware of the striking level of cast production. Though this is of uncertain and doubtful significance, these high doses of cephaloridine should be given only to patients where any such slight risk is justified.

\section{REFERENCES}

Allen, J. D., Roberts, C. E., and Kirby, W. M. M. (1962). New Engl. J. Med., 266, 111.

Campbell, M. F. (1963). Urology, vol. I, p. 219. Saunders, Philadelphia and London.

Feigin, R. D., and Fiascone, A. (1965). New Engl. J. Med., 272, 903.

Grattan, W. A. (1964). J. Pediat., 64, 285.

Pines, A. (1964). Lancet, 2, 445.

, Raafat, H., Plucinski, K., Greenfield, J. S. B., and Linsell. W. D. (1967). Brit. J. Dis. Chest, 61, 101.

Sodeman, W. A. (1961). Pathologic Physiology, 3rd. ed., p. 836 Saunders, Philadelphia and London. 